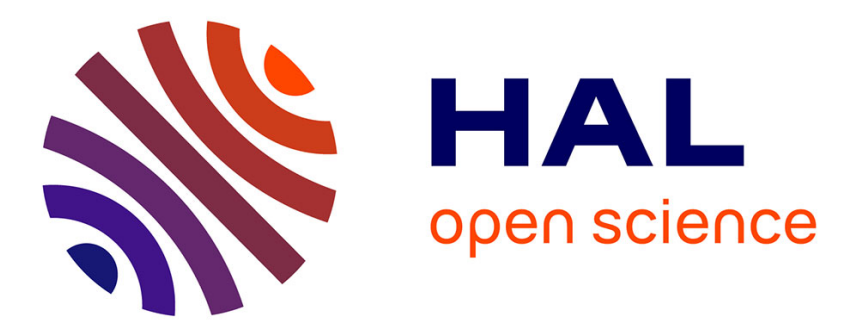

\title{
Identification of FOXP1 and SNX2 as novel ABL1 fusion partners in acute lymphoblastic leukaemia
}

Thomas Ernst, Joannah Score, Claire Hidalgo-Curtis, Michael Wn Deininger, Peter M Lackie, William B Ershler, John M Goldman, Nicholas C.P. Cross, Francis Hector Grand

\section{To cite this version:}

Thomas Ernst, Joannah Score, Claire Hidalgo-Curtis, Michael Wn Deininger, Peter M Lackie, et al.. Identification of FOXP1 and SNX2 as novel ABL1 fusion partners in acute lymphoblastic leukaemia. British Journal of Haematology, 2011, 153 (1), pp.43. 10.1111/j.1365-2141.2010.08457.x . hal00612830

\section{HAL Id: hal-00612830 \\ https://hal.science/hal-00612830}

Submitted on 1 Aug 2011

HAL is a multi-disciplinary open access archive for the deposit and dissemination of scientific research documents, whether they are published or not. The documents may come from teaching and research institutions in France or abroad, or from public or private research centers.
L'archive ouverte pluridisciplinaire HAL, est destinée au dépôt et à la diffusion de documents scientifiques de niveau recherche, publiés ou non, émanant des établissements d'enseignement et de recherche français ou étrangers, des laboratoires publics ou privés. 


\section{bjh british journal of haematology}

\section{Identification of FOXP1 and SNX2 as novel ABL1 fusion partners in acute lymphoblastic leukaemia}

\begin{tabular}{|r|l|}
\hline Journal: & British Journal of Haematology \\
\hline Manuscript ID: & BJH-2010-00999 \\
\hline Manuscript Type: & Short Reports \\
\hline Author: & 24-Jun-2010 \\
\hline Complete List of Authors: & $\begin{array}{l}\text { Ernst, Thomas; Universitätsklinikum Jena, Klinik für Innere Medizin } \\
\text { II } \\
\text { Score, Joannah; University of Southampton, Wessex Regional } \\
\text { Genetics Laboratory } \\
\text { Hidalgo-Curtis, Claire; University of Southampton, Wessex Regional } \\
\text { Genetics Laboratory } \\
\text { Deininger, Michael; Oregon Health and Science University, } \\
\text { Hematology } \\
\text { Lackie, Peter; University of Southampton, Infection Inflammation } \\
\text { and Immunity } \\
\text { Ershler, William; Harbor Hospital, Hematology/Immunology Unit } \\
\text { Goldman, John; Imperial College London, Haematology } \\
\text { Cross, Nicholas; University of Southampton, Salisbury District } \\
\text { Hospital, Wessex Regional Genetics Laboratory } \\
\text { Grand, Francis; University of Southampton, Wessex Regional } \\
\text { Genetics Laboratory }\end{array}$ \\
\hline Key Words: & \begin{tabular}{l} 
ABL, ACUTE LEUKAEMIA, IMATINIB \\
\hline \hline
\end{tabular} \\
\hline
\end{tabular}

\section{s ScholarONE"




\section{Identification of $F O X P 1$ and $S N X 2$ as novel $A B L 1$ fusion partners in acute lymphoblastic leukaemia}

Thomas Ernst ${ }^{1}$, Joannah Score ${ }^{2}$, Michael Deininger ${ }^{3}$, Claire Hidalgo-Curtis ${ }^{2}$, Peter Lackie ${ }^{4}$, William B Ershler ${ }^{5}$, John M Goldman ${ }^{6}$, Nicholas C.P. Cross ${ }^{2}$ and Francis H. Grand ${ }^{2}$

${ }^{12}$ Universitätsklinikum Jena, Klinik für Innere Medizin II Jena, Germany

${ }^{2}$ Wessex Regional Genetics Laboratory, University of Southampton, Salisbury, United Kingdom

${ }^{3}$ Oregon Health and Science University, Hematology

Portland, Oregon, United States

${ }^{4}$ University of Southampton, Infection Inflammation and Immunity Southampton, United Kingdom

${ }^{5}$ Harbor Hospital, Hematology/Immunology Unit Baltimore, Maryland, United States

${ }^{6}$ Harbor Hospital, Hematology/Immunology Unit Baltimore, Maryland, United States

Keywords: ABL1, FOXP1, SNX2, ALL, acute lymphoblastic leukaemia

Running title: FOXP1-ABL1 and SNX2-ABL1 fusion genes in B-ALL 


\section{Corresponding author:}

Francis H. Grand, PhD

Wessex Regional Genetics Laboratory

University of Southampton

Salisbury SP2 8BJ

United Kingdom

Tel: $\quad+(44) 1722429080$

Fax: $\quad+(44) 1722338095$

E-Mail: F.H.Grand@ @oton.ac.uk 


\section{Summary}

We have identified two novel $A B L 1$ fusion genes in two patients with B-cell acute lymphoblastic leukaemia associated with a $\mathrm{t}(3 ; 9)(\mathrm{p} 12 ; \mathrm{q} 34)$ and a $\mathrm{t}(5 ; 9)(\mathrm{q} 23 ; \mathrm{q} 34)$, respectively. Molecular analysis revealed a FOXP1-ABL1 fusion for the $\mathrm{t}(3 ; 9)$ and a $S N X 2$ $A B L 1$ fusion for the $\mathrm{t}(5 ; 9)$. The fusions were confirmed by specific amplification of the genomic breakpoints using reverse transcription polymerase chain reaction (RT-PCR). The identification of ALL with rare ABL1 fusion partners is important because the leukaemia may respond to tyrosine kinase inhibitors in the same way as ALL patients with a classical $B C R$ $A B L 1$ fusion gene. 


\section{Introduction}

Constitutively activated mutants of the non-receptor tyrosine kinase ABL1 play a central role in the pathogenesis of clinically and morphologically distinct chronic and acute leukaemias (Chase \& Cross, 2006). By far the most frequent and best-studied ABL1 fusion gene is BCR$A B L$, which results from an acquired reciprocal $\mathrm{t}(9 ; 22)(\mathrm{q} 34 ; \mathrm{q} 11)$ (Shtivelman et al, 1985; Ben-Neriah et al, 1986). The $\mathrm{t}(9 ; 22)(\mathrm{q} 34 ; \mathrm{q} 11)$ is found in virtually all patients with chronic myeloid leukaemia (CML), in approximately $20 \%$ of adults with B-cell acute lymphoblastic leukaemia (ALL), and in rare cases of acute myeloid leukaemia (Fröhling \& Döhner 2008). The second most frequent and biologically distinct $A B L 1$ fusion gene is NUP214-ABL1 in TALL (Graux et al, 2004). Remarkably, this fusion is generated by circularisation of the $500 \mathrm{~kb}$ genomic region from $A B L 1$ to $N U P 214$ and subsequent extrachromosomal (episomal) amplification. Other $A B L 1$ fusion genes have been described but are uncommon. The ETV6$A B L 1$ fusion gene is the product of a $\mathrm{t}(9 ; 12)(\mathrm{q} 34 ; \mathrm{p} 13)$ and is found in occasional patients with acute leukaemias or atypical CML (Papadopoulos et al, 1995; Golub et al, 1996; Andreasson et al, 1997). EML1-ABL1 was found in a single female patient with T-ALL and a cryptic t(9;14)(q34;q32) (De Keersmaecker et al, 2005). Recently, RCSD1, ZMIZ1 and SFPQ were identified as novel ABL1 fusion partners in single cases of B-ALL (De Braekeleer et al, 2007; Soler et al, 2008; Hidalgo-Curtis et al, 2008).

Imatinib is a specific inhibitor of several tyrosine kinases including ABL1 and induces longterm complete haematologic and cytogenetic remissions in most patients with chronic phase CML (Druker et al, 2001; Deininger et al, 2009). However, a substantial proportion of patients with advanced phase CML or $B C R-A B L 1$ positive ALL are initially refractory to 
imatinib treatment or lose imatinib sensitivity over time and relapse (Apperley, 2007; Pui et $a l, 2008$ ). More potent second-generation ABL1 kinase inhibitors (e.g. dasatinib, nilotinib, bosutinib) have been developed for the treatment of imatinib-resistant patients and emerging clinical data indicate that these drugs have promising efficacy (Weisberg et al, 2007, Gruber et al, 2009). Both, first- and second-generation ABL1 kinase inhibitors are expected to achieve similar remission rates in patients with $A B L 1$ fusion genes other than $B C R-A B L 1$. However, because the majority of these cases have only been reported in individual patients, insufficient data on the in-vivo efficacy of tyrosine kinase inhibitors are currently available. NUP214-ABL and EML1-ABL have been shown to be imatinib sensitive in-vitro and two single case reports documented dasatinib sensitivity for NUP214-ABL and RCSD1-ABL invivo (Deenik et al, 2009; Mustjoki et al, 2009).

In this study, we have investigated two B-ALL patients with acquired chromosomal rearrangements each involving the chromosomal band $9 \mathrm{q} 34$ and identified two novel $A B L 1$ fusion genes potentially sensitive to imatinib treatment. Although these fusion genes occur rarely, their identification is essential in order to detect patients in whom targeted treatment with tyrosine kinase inhibitors is likely to be successful. Furthermore, molecular definition of novel fusion partners for known kinases remains important both for rapid molecular diagnosis of new cases and for monitoring an individual patient's response to treatment. 


\section{Patients and methods}

\section{Patients}

Case 1: FOXP1-ABL1 male/female B-ALL with t(3;9)(p12;q34).

A 16-year old caucasian woman was diagnosed with pre B cell acute lymphoblastic leukaemia in October 2001, with an initial white blood cell count of $>50,000 / \mathrm{nL}$. Her past medical history was significant only for recurrent deep venous thrombosis secondary to protein $\mathrm{S}$ deficiency. Bone marrow cytogenetics was 46XX,t(3;9)(p12;q34)[20]. FISH revealed loss of one copy of the p16 locus. Based on her age and an initial white blood count she was considered high risk. Treatment was initiated according to the standard arm for high risk patients of the COALL-97 protocol of the German Cooperative Study Group for Childhood Acute Lymphoblastic Leukaemia (COALL). Therapy was complicated by recurrent DVT, catheter-associated septicaemia and steroid-induced diabetes mellitus. She achieved a complete response and in February 2002 was consolidated with a haplo-identical transplant from her father. Complications included grade III GvHD of the skin and fungal pneumonia, both of which resolved on therapy. On last follow-up in spring of 2010 she continued in CR, with excellent functionality (attending medical school).

Case 2: $S N X 2-A B L 1$ male B-ALL with $\mathrm{t}(5 ; 9)(\mathrm{q} 23 ; \mathrm{q} 34)$.

The patient was diagnosed in April 2004 aged 29 when he presented with a WBC of 161 x10\%1. The cell showed a classical B-cell immunophenotype. Bone marrow cytogenetics showed a $\mathrm{t}(5 ; 9)(\mathrm{q} 23 ; \mathrm{q} 34)$ and a 20q-. FISH showed evidence of the ABL gene on both derivative chromosomes. BCR was apparently not involved. He responded well to initial 
chemotherapy but relapsed early. He then received hyper-C-VAD and again responded. He relapsed again at the end of 2004 and was started on imatinib, it was transient and despite other supportive measures including hydroxyurea he died in Spring 2005.

\section{Fluorescence In Situ Hybridization (FISH)}

To our knowledge, no other cases have been reported with a $t(3 ; 9)(\mathrm{p} 14 ; \mathrm{q} 34)$ or $\mathrm{t}(5 ; 9)(\mathrm{q} 23 ; \mathrm{q} 34)$. For the $\mathrm{t}(5 ; 9)$ FISH was performed using the BCR-ABL probe from Abbott.

\section{5' Rapid Amplification of cDNA Ends (5'RACE) PCR}

Partner genes were identified using the Gene-Racer ${ }^{\mathrm{TM}}$ Kit (Invitrogen, Paisley, UK). Briefly, $\sim 5 \mu \mathrm{g}$ of total RNA extracted using the Qiagen RNeasy kit (Qiagen, Boundary Court, UK) was dephosphorylated, decapped, and ligated to the GeneRacer ${ }^{\mathrm{TM}}$ RNA oligo according to the manufacturer's instructions. The ligated RNA was reverse transcribed using Superscript $\mathrm{II}^{\mathrm{TM}}$ reverse transcriptase (Invitrogen, Paisley, UK) and random primers (100 ng). Single step 5' RACE PCR was performed using the 5' GeneRacer ${ }^{\mathrm{TM}}$ primer from the kit in combination with a reverse primer from ABL1 exon 4 (1R: 5'-cca ccg ttg aat gat gat gaa cc-3'). The PCR cycles were designed to amplify fragments up to $3 \mathrm{~kb}$, with an annealing temperature of $66^{\circ} \mathrm{C}$ using the High Fidelity PCR Master kit (Roche, Mannheim, Germany) according to the manufacturer's instructions. Products were cloned with the TOPO TA Cloning Kit for Sequencing (Invitrogen, Paisley, UK) and sequenced.

RT-PCR Methods 
Case 1: The presence of FOXP1-ABL1 mRNA was confirmed on random hexamer reverse transcribed cDNA using primers to FOXP1 exon 18 (5'-gca gta tgg aca gtg gat gaa gta-3') with the reverse ABL1 exon 4 (see above). These primers were also used to amplify the genomic breakpoint.

Case 2: The presence of SNX2-ABL1 mRNA was confirmed on random hexamer reverse transcribed cDNA using primers to SNX2 1F new (5'-aag agt atg tct gct ccc gtg atc tt-3') with the reverse ABL1 exon 4. These primers were also used to amplify the genomic breakpoint.

\section{Results}

\section{Characterization of the $t(3 ; 9)(p 14 ; q 34)$}

FISH using the probes that immediately flank the ABL1 gene hybridized to the normal copy of chromosome 9, also the $\operatorname{der}(9)$ and the der(3), indicating that the translocation targeted ABL1; however, no BCR-ABL1 fusion was seen by FISH or RT-PCR. Most ABL1 fusions reported to date result in the partner gene fusing to ABL1 exons 2 or 3 . To identify the $t(3 ; 9)$ partner, we, therefore, performed 5'-RACE PCR from both these exons. These initial attempts failed despite the fact that normal 5' ABL1 sequence was readily obtained (data not shown). 5' RACE primers were subsequently designed in ABL1 exon 4 (ENST00000318560). Sequencing of the products revealed several clones in which FOXP1 (ENST00000318789) exon 19 was fused in frame to ABL1 exon 4.

\section{Confirmation of the FOXP1-ABL1 fusion}

The presence of the FOXP1-ABL1 fusion was confirmed initially by RT-PCR. The reciprocal ABL1-FOXP1 product was detectable by single step PCR. Cloning and sequencing revealed 
that the reciprocal product fuses ABL1 exon 3 to an alternative RNA isoform (NM_032682) of FOXP1. As shown in Figure 1a and 1b, the FOXP1-ABL1 fusion was specifically amplified from patient cells by single step PCR, but was not detectable in normal controls. To further confirm the presence of the fusion the genomic breakpoint was amplified by long PCR, cloned, and sequenced.

\section{Characterization of the $t(5 ; 9)(q 23 ; q 34)$}

FISH using the Abbott BCR-ABL1 probes that immediately flank the ABL1 gene hybridized to the normal copy of chromosome 9 , also the $\operatorname{der}(9)$ and the $\operatorname{der}(5)$, indicating that the translocation targeted ABL1; however, no BCR-ABL1 fusion was seen by FISH or RT-PCR. 5' RACE PCR form ABL1 exons 2 and 3 failed, after the previous cloning of the $t(3 ; 9)$ translocation, 5'-RACE PCR primers were designed in ABL1 exon 4 (ENST00000318560). Sequencing of the products revealed several clones in which SNX2 (ENST00000379516) exon 3 was fused in frame to ABL1 exon 4.

\section{Confirmation of the SNX2-ABL1 fusion}

The presence of the SNX2-ABL1 fusion was confirmed initially by RT-PCR. The reciprocal $A B L 1-S N X 2$ product was not detectable by single step PCR. As shown in Figure $2 \mathrm{a}$ and $2 \mathrm{~b}$, the SNX2-ABL1 fusion was specifically amplified from patient cells by single step PCR, but was not detectable in normal controls. To further confirm the presence of the fusion the genomic breakpoint was amplified by long PCR, cloned, and sequenced (data not shown). 


\section{Discussion}

This study has characterised the genomic breakpoints in two B-ALL cases with chromosome 9q34 rearrangements and identified FOXP1 at 3p14 and SNX2 at 5q23 as novel ABL1 fusion partners. This brings the number of known $A B L 1$ partner genes to nine. In the chimeric protein, $\mathrm{N}$-terminal sequences of ABL1 are replaced by amino-acids derived from the partner protein that provides dimerisation motifs essential for the transforming activity of ABL1. Fusion genes involving $A B L 1$ are excellent drug targets as exemplified by the activity of imatinib in $B C R-A B L 1$ positive diseases, particularly CML. The clinical course of patients with $A B L 1$ fusion genes other than $B C R-A B L 1$ may be different and highly dependent on the underlying disease. Response rates and risk of relapse may be similar to CML in patients with chronic phase myeloproliferative neoplasms or similar to $B C R-A B L 1$ positive ALL in patients with acute leukaemias, respectively. As the fusions described here were referred specifically for investigation of $9 q$ rearrangements and were not part of a series that underwent systemic cytogenetic investigation, it is not possible to accurately determine the frequency of these abnormalities. However, we estimate that they probably account for $<1 \%$ of ALL cases.

The $A B L 1$ gene is located on chromosome band $9 \mathrm{q} 34$ and encodes a ubiquitously cytoplasmic and nuclear protein tyrosine kinase that has been implicated in processes of cell differentiation, cell division, cell adhesion, and stress response. Simplified, the structure of ABL1 consists of $\mathrm{N}$-terminal $\mathrm{SH} 3$ and $\mathrm{SH} 2$ domains (which mediate binding to proline-rich and phosphotyrosine proteine ligands, respectively), a catalytic tyrosine kinase domain that contains phosphotransferase activity and a DNA-binding domain with yet largely unknown effects and a C-terminal actin-binding domain. Most previously described fusion genes involving $A B L 1$ fuse with $A B L 1$ exon 2 . However, similar to the recently described fusion 
partners $S F P Q$ and RCSDI (Hildalgo-Curtis et al, 2008; Mustjoki et al, 2009) both partner genes described here fuse to $A B L 1$ exon 4. These are structurally unusual $A B L 1$ fusion proteins as the $\mathrm{SH} 3$ and $\mathrm{SH} 2$ domains are not included. Mouse models with BCR-ABL1 constructs in which the SH2 domain was inactivated have shown that the fusion protein retained the ability to cause leukaemia in mice (Roumiantsev et al, 2001).

The FOXP1 gene is located at 3p14 and encodes a member of the forkhead box (FOX) family of transcription factors with diverse functions in development, metabolism, organogenesis and cancer (Hannenhalli \& Kaestner, 2009). FOXP1 was first cloned from the mouse B-cell leukaemia cell line BCL1 and later described to be an essential transcriptional regulator of B lymphopoiesis via direct regulation of the B-cell specific Erag enhancer (Li \& Tucker, 1993; Hu et al, 2006). FOXPl has been described as a recurrent translocation partner of the IGH gene in a subset of MALT lymphomas and diffuse large B-cell lymphomas with $\mathrm{t}(3 ; 14)(\mathrm{p} 14 ; \mathrm{q} 32)$ (Streubel et al, 2005; Wlodarska et al, 2005). Furthermore, FOXP1 was identified as a translocation partner of PAX5 in a single case of paediatric B-ALL (Mullighan et al, 2007). In contrast to previously published studies, we found FOXP1 as the 5' partner of the fusion gene. Nearly the entire FOXP1 gene including the forkhead domain was fused in 5' position to $A B L 1$.

The SNX2 gene is located at 5q23 and belongs to the sortin nexins (SNX) family that function within the endocytic network, including endocytosis, endomsomal sorting and endosomal signalling (Cullen, 2008). SNX2 is expressed at high levels in CD34 positive bone marrow cells and thought to heterodimerise with $S N X 1$ in a retromer protein complex. The retromer is a vesicle coat complex that helps in protein sorting between the Golgi and endosomes, playing a key role in protecting some receptors from lysosomal destruction (Seaman, 2005). The hallmark of SNX family is the presence of a PX domain - a sequence of approximately 100- 
130 amino acids that has been shown to bind various phosphatidylinositol phosphates, thereby potentially targeting these proteins to specific cellular membranes that are enriched in these phospholipids (Worby \& Dixon, 2002). As described above, constitutive activation of ABL fusion genes is mediated by an oligomerisation domain in the partner protein. The SNX2$A B L 1$ fusion gene is unusual as it lacks a clearly recognisable dimerisation motif. The Nterminal domain of SNX2 - without the PX domain - is fused to ABL1 exon 4.

\begin{abstract}
Although rare the potential sensitivity to imatinib implies that these fusions should be searched for in acute leukaemia. The screen for such uncommon, but clinically significant fusion transcripts can easily be included in multiplex PCR panels used in routine diagnostic work-ups. Targeted therapy has revolutionised the treatment of CML and there is considerable optimism that targeting $A B L 1$ fusion genes other than $B C R-A B L 1$ will bring at least short term benefits for those patients. On the other hand, targeted therapy is very expensive and it will be important to develop markers to identify those patients who are most likely to benefit from treatment.
\end{abstract}

\title{
Acknowledgements
}

TE was supported by the Dr Mildred Scheel Stiftung für Krebsforschung (Deutsche Krebshilfe e.V.). 


\section{References}

Andreasson, P., Johansson, B., Carlsson, M., Jarlsfelt, I., Fioretos, T., Mitelman, F. \& Hoglund, M. (1997) BCR/ABL-negative chronic myeloid leukemia with ETV6/ABL fusion. Genes Chromosomes Cancer, 20, 299-304.

Apperley, J.F. (2007) Part I: mechanisms of resistance to imatinib in chronic myeloid leukaemia. Lancet Oncol, 8, 1018-1029.

Ben-Neriah, Y., Daley, G.Q., Mes-Masson A.M., Witte, O.N. \& Baltimore, D. (1986)

The chronic myelogenous leukemia-specific P210 protein is the product of the bcr/abl hybrid gene. Science, 233, 212-214.

Chase, A. \& Cross, N.C. (2006) Signal transduction therapy in haematological malignancies: identification and targeting of tyrosine kinases. Clin Sci (Lond), 111, 233-249.

Cullen, P.J. (2008) Endosomal sorting and signalling: an emerging role for sorting nexins. Nat Rev Mol Cell Biol, 9, 574-582.

De Braekeleer, E., Douet-Guilbert, N., Le Bris, M.J., Berthou, C., Morel, F. \& De Braekeleer, M. (2007) A new partner gene fused to ABL1 in a t(1;9)(q24;q34)-associated B-cell acute lymphoblastic leukemia. Leukemia, 21, 2220-2221.

De Keersmaecker, K., Graux, C., Odero, M.D., Mentens, N., Somers, R., Maertens, J., Wlodarska, I., Vandenberghe, P., Hagemeijer, A., Marynen, P. \& Cools, J. (2005) Fusion of EML1 to ABL1 in T-cell acute lymphoblastic leukemia with cryptic $\mathrm{t}(9 ; 14)(\mathrm{q} 34 ; \mathrm{q} 32)$. Blood, 105, 4849-4852.

Deenik, W., Beverloo, H.B., van der Poel-van de Luytgaarde, S.C., Wattel, M.M., van Esser, J.W., Valk, P.J. \& Cornelissen, J.J. (2009) Rapid complete cytogenetic remission after upfront dasatinib monotherapy in a patient with a NUP214-ABL1-positive T-cell acute lymphoblastic leukemia. Leukemia, 23, 627-629.

Deininger, M., O'Brien, S.G., Guilhot, F., Goldman, J.M., Hochhaus, A., Hughes, T.P., Radich, J.P., Hatfield, A.K., Mone, M., Filian, J., Reynolds, J., Gathmann, I., Larson, R.A. \& Druker, B.J. (2009) International randomized study of interferon vs STI571 (IRIS) 8-year follow up: sustained survival and low risk for progression or events in patients with newly diagnosed chronic myeloid leukemia in chronic phase (CML-CP) Treated with Imatinib. Blood (ASH annual meeting abstracts), 114, [1126].

Druker, B.J., Talpaz, M., Resta, D.J., Peng, B., Buchdunger, E., Ford, J.M., Lydon, N.B., Kantarjian, H., Capdeville, R., Ohno-Jones, S. \& Sawyers, C.L. (2001) Efficacy and safety of a specific inhibitor of the BCR-ABL tyrosine kinase in chronic myeloid leukemia. $N$ Engl J Med, 344, 1031-1037.

Frohling, S. \& Dohner, H. (2008) Chromosomal abnormalities in cancer. N Engl J Med, 359, 722-734.

Golub, T.R., Goga, A., Barker, G.F., Afar, D.E., McLaughlin, J., Bohlander, S.K., Rowley, J.D., Witte, O.N. \& Gilliland, D.G. (1996) Oligomerization of the ABL tyrosine kinase by the Ets protein TEL in human leukemia. Mol Cell Biol, 16, 4107-4116.

Graux, C., Cools, J., Melotte, C., Quentmeier, H., Ferrando, A., Levine, R., Vermeesch, J.R., Stul, M., Dutta, B., Boeckx, N., Bosly, A., Heimann, P., Uyttebroeck, A., Mentens, N., Somers, R., MacLeod, R.A., Drexler, H.G., Look, A.T., Gilliland, D.G., Michaux, L., Vandenberghe, P., Wlodarska, I., Marynen, P. \& Hagemeijer, A. (2004) Fusion of NUP214 to ABL1 on amplified episomes in T-cell acute lymphoblastic leukemia. Nat Genet, 36, 1084-1089.

Gruber, F., Mustjoki, S. \& Porkka, K. (2009) Impact of tyrosine kinase inhibitors on patient outcomes in Philadelphia chromosome-positive acute lymphoblastic leukaemia. $\mathrm{Br} \mathrm{J}$ Haematol, 145, 581-597.

Hannenhalli, S. \& Kaestner, K.H. (2009) The evolution of Fox genes and their role in development and disease. Nat Rev Genet, 10, 233-240. 
Hidalgo-Curtis, C., Chase, A., Drachenberg, M., Roberts, M.W., Finkelstein, J.Z., Mould, S., Oscier, D., Cross, N.C. \& Grand, F.H. (2008) The $t(1 ; 9)(\mathrm{p} 34 ; \mathrm{q} 34)$ and $\mathrm{t}(8 ; 12)(\mathrm{p} 11 ; \mathrm{q} 15)$ fuse pre-mRNA processing proteins SFPQ (PSF) and CPSF6 to ABL and FGFR1. Genes Chromosomes Cancer, 47, 379-385.

Hu, H., Wang, B., Borde, M., Nardone, J., Maika, S., Allred, L., Tucker, P.W. \& Rao, A. (2006) Foxp1 is an essential transcriptional regulator of B cell development. Nat Immunol, 7, 819-826.

Li, C. \& Tucker, P.W. (1993) DNA-binding properties and secondary structural model of the hepatocyte nuclear factor 3/fork head domain. Proc Natl Acad Sci U S A, 90, 1158311587.

Mullighan, C.G., Goorha, S., Radtke, I., Miller, C.B., Coustan-Smith, E., Dalton, J.D., Girtman, K., Mathew, S., Ma, J., Pounds, S.B., Su, X., Pui, C.H., Relling, M.V., Evans, W.E., Shurtleff, S.A. \& Downing, J.R. (2007) Genome-wide analysis of genetic alterations in acute lymphoblastic leukaemia. Nature, 446, 758-764.

Mustjoki, S., Hernesniemi, S., Rauhala, A., Kahkonen, M., Almqvist, A., Lundan, T. \& Porkka, K. (2009) A novel dasatinib-sensitive RCSD1-ABL1 fusion transcript in chemotherapy-refractory adult pre-B lymphoblastic leukemia with $t(1 ; 9)(q 24 ; q 34)$. Haematologica, 94, 1469-1471.

Papadopoulos, P., Ridge, S.A., Boucher, C.A., Stocking, C. \& Wiedemann, L.M. (1995) The novel activation of ABL by fusion to an ets-related gene, TEL. Cancer Res, 55, 34-38.

Pui, C.H., Robison, L.L. \& Look, A.T. (2008) Acute lymphoblastic leukaemia. Lancet, 371, 1030-1043.

Roumiantsev, S., de Aos, I.E., Varticovski, L., Ilaria, R.L. \& Van Etten, R.A. (2001) The src homology 2 domain of $\mathrm{Bcr} / \mathrm{Abl}$ is required for efficient induction of chronic myeloid leukemia-like disease in mice but not for lymphoid leukemogenesis or activation of phosphatidylinositol 3-kinase. Blood, 97, 4-13.

Seaman, M.N. (2005) Recycle your receptors with retromer. Trends Cell Biol, 15, 68-75.

Shtivelman, E., Lifshitz, B., Gale, R.P. \& Canaani, E. (1985) Fused transcript of abl and bcr genes in chronic myelogenous leukaemia. Nature, 315, 550-554.

Soler, G., Radford-Weiss, I., Ben-Abdelali, R., Mahlaoui, N., Ponceau, J.F., Macintyre, E.A., Vekemans, M., Bernard, O.A. \& Romana, S.P. (2008) Fusion of ZMIZ1 to ABL1 in a B-cell acute lymphoblastic leukaemia with a $\mathrm{t}(9 ; 10)(\mathrm{q} 34 ; \mathrm{q} 22.3)$ translocation. Leukemia, 22, 1278-1280.

Streubel, B., Vinatzer, U., Lamprecht, A., Raderer, M. \& Chott, A. (2005) T(3;14)(p14.1;q32) involving IGH and FOXP1 is a novel recurrent chromosomal aberration in MALT lymphoma. Leukemia, 19, 652-658.

Weisberg, E., Manley, P.W., Cowan-Jacob, S.W., Hochhaus, A. \& Griffin, J.D. (2007) Second generation inhibitors of BCR-ABL for the treatment of imatinib-resistant chronic myeloid leukaemia. Nat Rev Cancer, 7, 345-356.

Wlodarska, I., Veyt, E., De Paepe, P., Vandenberghe, P., Nooijen, P., Theate, I., Michaux, L., Sagaert, X., Marynen, P., Hagemeijer, A. \& De Wolf-Peeters, C. (2005) FOXP1, a gene highly expressed in a subset of diffuse large B-cell lymphoma, is recurrently targeted by genomic aberrations. Leukemia, 19, 1299-1305.

Worby, C.A. \& Dixon, J.E. (2002) Sorting out the cellular functions of sorting nexins. Nat Rev Mol Cell Biol, 3, 919-931. 


\section{$\mathrm{t}(3 ; 9) \quad \mathrm{N} 1 \quad \mathrm{~N} 2 \quad \mathrm{~N} 3 \quad \mathrm{~B} 1 \quad \mathrm{~B} 2$}

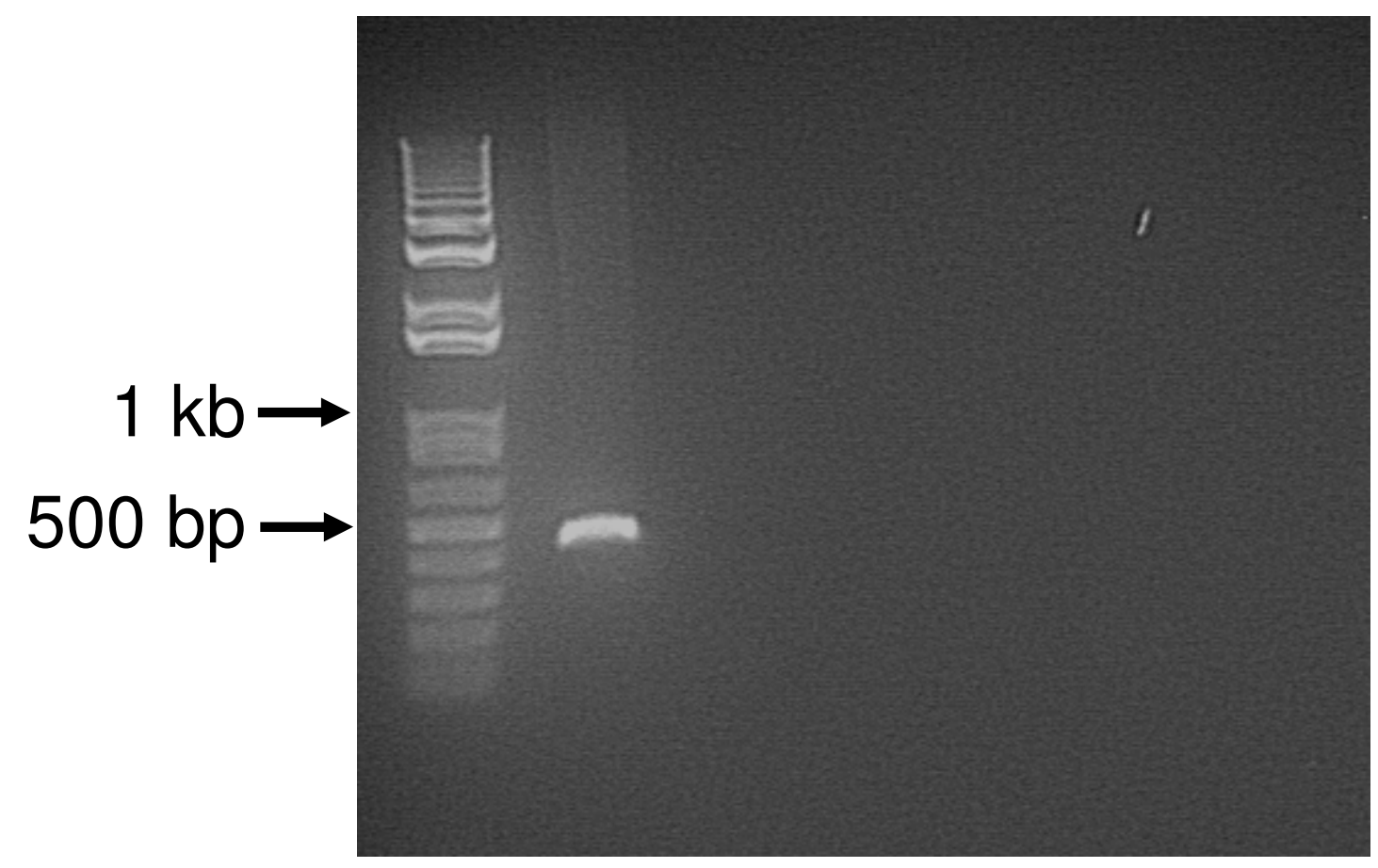




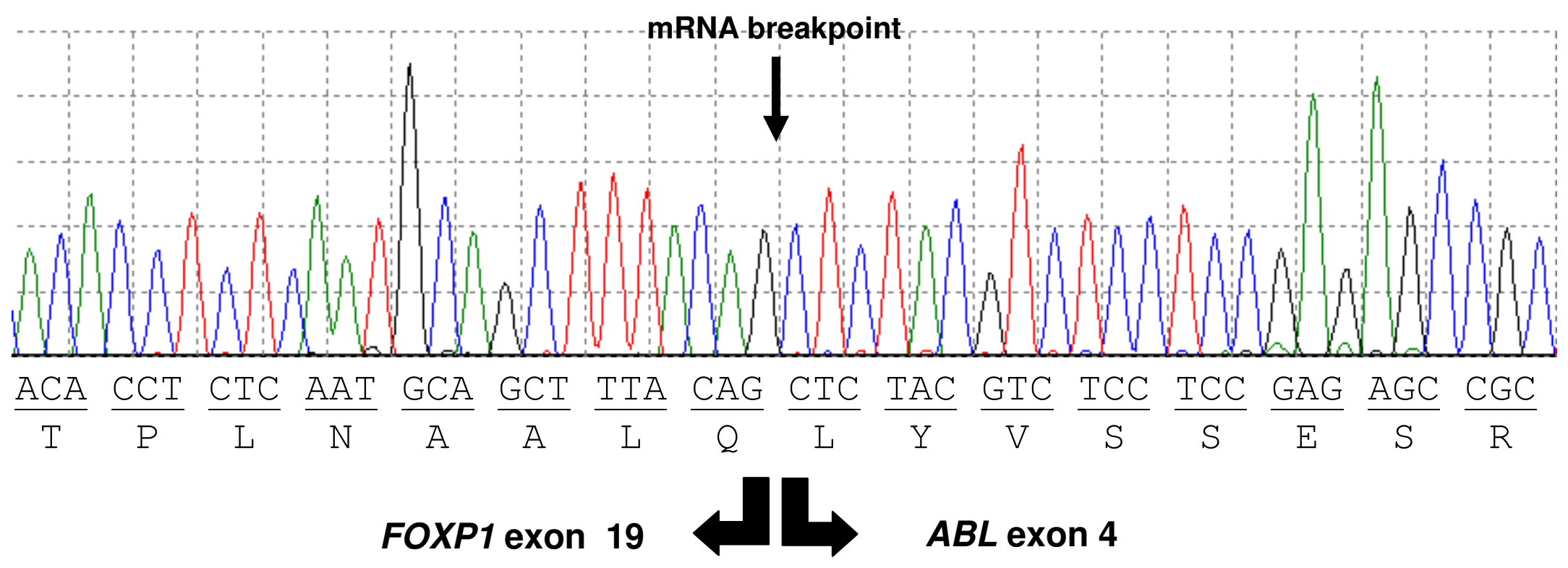


$\mathrm{t}(5 ; 9) \mathrm{N} 1 \quad \mathrm{~N} 2 \quad \mathrm{~N} 3 \quad \mathrm{~B} 1$

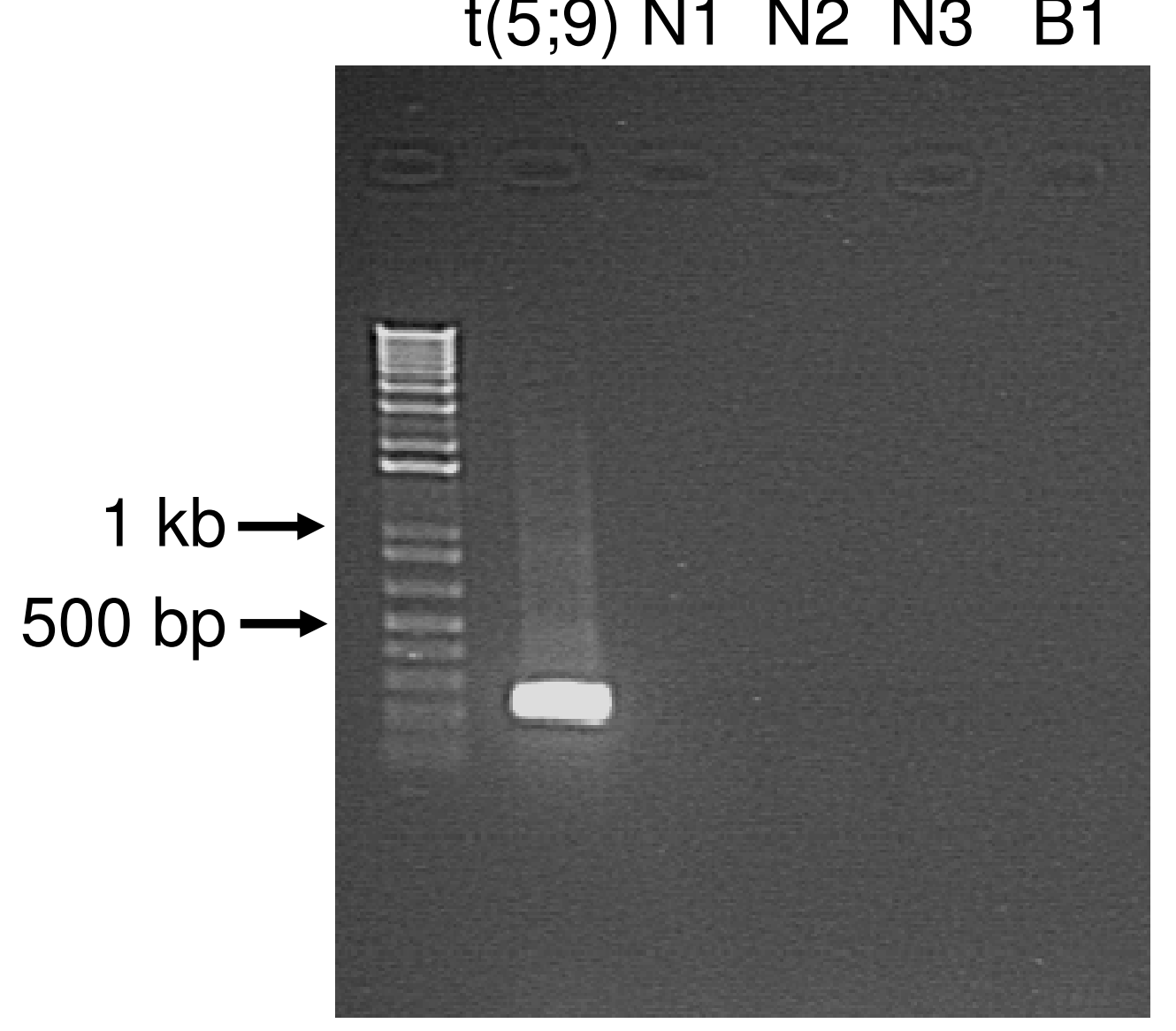




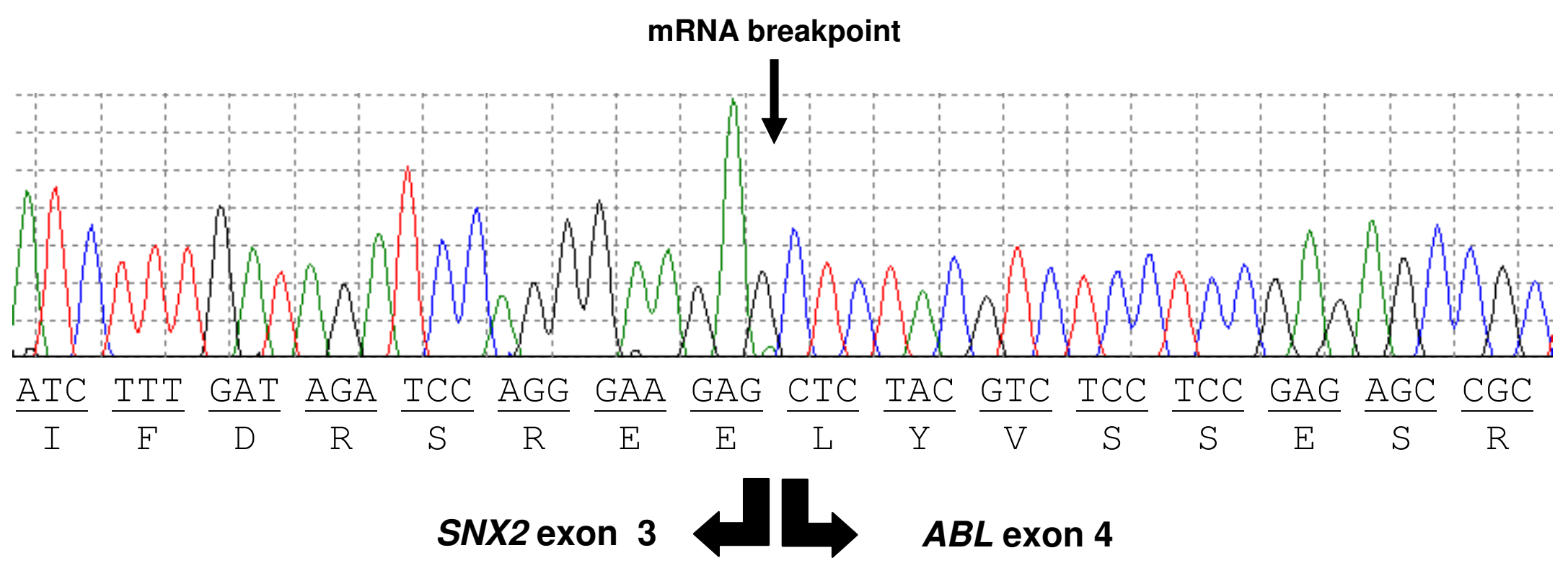

